\title{
Design and Simulation of Photovoltaic Cell Using Decrement Resistance Algorithm
}

\author{
Mukesh Kr. Gupta ${ }^{1 *}$ and Rohit Jain ${ }^{2}$ \\ 'Department of Electronic Instrumentation \& Control Engineering, Jagannath Gupta Institute of \\ Engineering \& Technology, Jaipur-302022, Rajasthan, India; mkgupta72@gmail.com \\ ${ }^{2}$ Department of Physics, Jagannath Gupta Institute of Engineering \& Technology, \\ Jaipur-302022, Rajasthan, India; rohitj23@rediffmail.com
}

\begin{abstract}
This paper presents a new approach of the Design and simulation of a photovoltaic cell using decrement resistance algorithm for maximum power point tracking (MPPT). The Simulation is done in the MATLAB. The algorithm detects the maximum power point of the photovoltaic (PV) cell. It includes module BP SX 150S for a solar photovoltaic. This module provides a maximum power of $150 \mathrm{~W}$. The current-voltage (I-V) \& power-voltage (P-V) characteristics are obtained for various values of solar irradiance keeping the cell temperature constant. The points indicating module voltage $\mathrm{V}_{\mathrm{mp}}$ and current $\mathrm{I}_{\mathrm{mp}}$ at maximum Power $\mathrm{P}_{\text {max }}$ are obtained.
\end{abstract}

Keywords: PV Module, MPPT, MATLAB/ Simulation, Irradiance, Decrement Resistance Algorithm.

\section{Introduction}

The recent change in the environmental conditions such as global warning and rapid increase in the demand for electricity led to a need for a new source of energy that is cheaper and sustainable with less carbon emissions. Solar energy has offered promising result in the quest of finding the solution to the problem. The harnessing of solar energy using photovoltaic (PV) modules comes with its own problem that arises from the change in insulation conditions. These changes in insulation conditions severely affect the efficiency and output power of the PV modules [1-3].

The solar PV power system can be operated as a standalone, hybrid or grid connected systems. The solar PV cell has nonlinear V-I and P-V characteristics, which depends on the irradiance, the operating temperature and load condition of the cell [4]. Walker [5] proposed a MALAB based model of a PV module to simulate its characteristics for studying the effect of temperature, irradiation, and load variation on the available power. Hiren Patel and Vivek Agarwal [6] proposed the MATLAB based modeling and study the effects of partial shading on PV array characteristics. PV module characteristics and mathematical modeling are comprehensively discussed in [7-13], which indicate an exponential and nonlinear relation between the output current and voltage of PV module.

Proposed improved PV modules for the development of method for the mathematical modeling of PV arrays to validate the V-I characteristics of practical solar PV array are depicted.

The solar energy is a dilute source of energy and its availability varies widely with time. So, it is very necessary to make a complete utilization of solar energy in available time. Many MPPT algorithms are available for a solar panel in order to produce maximum output. It is very necessary that it is operated consistently at the maximum

\footnotetext{
* Corresponding author:

Mukesh Kr. Gupta (mkgupta72@gmail.com)
} 
power point. The decrement resistance algorithm of MPPT is described here with its maximum power point.

\section{PV Module}

This module of a photovoltaic system is based in a MATLAB. A simple module of a PV cell consist of an ideal current source in parallel with an ideal diode is shown as an equivalent circuit below Figure 1. [14, 15].

The two key parameters most often used to characterized a PV cell are its short-circuit current $\left(\mathrm{I}_{\mathrm{sc}}\right)$ and its open-circuit voltage $\left(\mathrm{V}_{\mathrm{oc}}\right)$ as shown in Figure 1. The Module manufacturer usually provides the values of these parameters in their datasheets [16]. The output current (I) from the equivalent circuit of a simple PV cell is found by applying the Kirchhoff's Current Law (KCL) [14]

$$
I=I_{s c}-I_{d}
$$

where I is the module current, $\mathrm{I}_{\mathrm{sc}}$ is the short-circuit current that is equal to the photon generated current, and $\mathrm{I}_{\mathrm{d}}$ is the current shunted through intrinsic diode. The diode current $I_{d}$ is given by the Shockley's diode equation:

$$
I_{d}=I_{o}\left(e^{q V / k T}-1\right),
$$

where $I_{0}$ is the reverse saturation current of diode (A); $\mathrm{q}$ is the electron charge $\left(1.602 \times 10^{-19} \mathrm{C}\right)$; $\mathrm{V}$ is the voltage across the PV cell (V); $\mathrm{k}$ is the Boltzmann's constant (1.38 $\left.\times 10^{-23} \mathrm{~J} / \mathrm{K}\right) ; \mathrm{T}$ is the junction temperature in Kelvin $(\mathrm{K})$. Combining the diode equation with the equation of the output current of the PV cell

$$
I=I_{s c}-I_{o}\left(e^{q V / k T}-1\right) .
$$

The reverse saturation current of diode $\left(\mathrm{I}_{\mathrm{o}}\right)$ is constant under the constant temperature, let $\mathrm{I}=0$ (no output current)

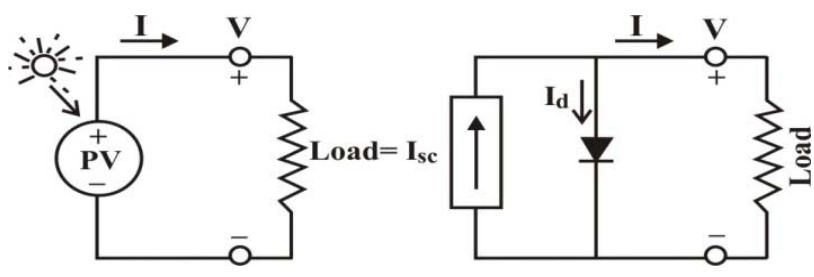

Figure 1. The equivalent circuit of a simple PV cell.

$$
\begin{aligned}
0 & =I_{s c}-I_{o}\left(e^{q V / k T}-1\right), \\
I_{s c} & =I_{o}\left(e^{q V / k T}-1\right), \\
I_{o} & =\frac{I_{s c}}{\left(e^{q V / k T}-1\right)} .
\end{aligned}
$$

There are a few things that have not been taken into account in the simple model and that will affect the performance of a PV cell in practice. In order to create more accurate model, series resistance (Rs), parallel resistance (Rp), and recombination must be factored into the equation as shown in Figure 2 [14].

Taking into account these additional elements add to the equation, the two diodes can be recombined to simplify the equation to:

$$
I=I_{s c}-I_{o}\left(e^{q(V+I \times R s) / n k T}-1\right)-\frac{(V+I \times R s)}{R p},
$$

where $\mathrm{n}$ is known as the idelity factor and takes the value between 1 and 2 .

The equivalent circuit with didoes combined and $\mathrm{Rp}=\infty$ is shown in Figure 3. Science it does not include the effect of parallel resistance (Rp), letting $\mathrm{Rp}=\infty$ in the equation (5) gives the equation [14] that describes the current-voltage relationship of the PV cell, and it shows below

$$
I=I_{s c}-I_{o}\left(e^{q(V+I \times R s) / n k T}-1\right) .
$$

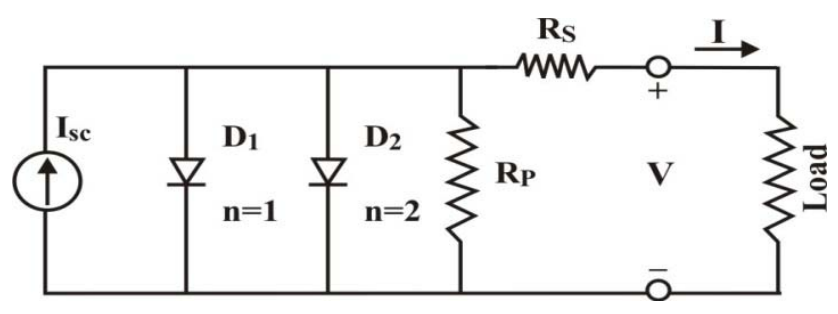

Figure 2. More accurate equivalent circuit of PV cell.

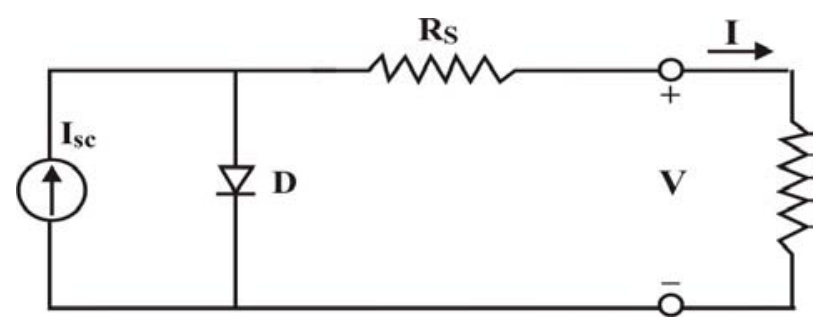

Figure 3. Equivalent circuit with diodes combined and $\mathrm{Rp}=\infty$. 
Finally, it is possible to solve the equation of I-V characteristics (6). It is, however, complex because the solution of current is recursive by inclusion of a series resistance in the model. Although it may be possible to find the answer by simple iterations, the Newton's method is chosen for rapid convergence of the answar [14]

$$
I_{n-1}=I_{n}-\left[\frac{I_{s c}-I_{n}-I_{o}\left(e^{\left(V+I_{n} \times R s\right) / n k T}-1\right)}{-1-I_{o}\left[\frac{q \times R s}{n k T}\right] e^{q\left(V+I_{n} \times R s\right)} / n k T}\right] .
$$

The MATLAB function written in this paper performs the calculation five times iteratively to ensure convergence of the result.

The value of the photon generated current $I_{s c}$ can be directly proportional to the irradiance, and the short circuit current is given under standard test conditions, $\mathrm{G}_{\mathrm{o}}=1000 \mathrm{~W} / \mathrm{m}^{2}$, which is provided on the data sheet [16].

Since a single PV cell produces an output voltage of less than 1 volt, it is necessary to string together a number of PV cell in series to achieve a desired output voltage. Generally, 36 cells in series will provide a large enough voltage to charge a 12 volt battery, and 72 cells would be suitable for a 24 volt battery. The BP SX 150 S PV module, which contains 72 cells, is selected for the purpose of this paper.

\section{Simulation of PV Module in MATLAB}

The characteristic equations (3), (4), (5), (6), \& (7) for the $\mathrm{PV}$ module is implemented in MATLAB. The parameters chosen for modeling corresponds to the BP SX150s module as listed in Table 1 . The voltage $\mathrm{V}$ is considered varying from 0 to Voc corresponding to the variation in current from $\mathrm{I}_{\mathrm{sc}}$ to 0 . Figure 4, 5, \& 6 shows the V-I, P-V, and P-I curves at various module temperatures simulated with the MATLAB model for BP SX 150s PV module.

\section{Decrement Resistance Algorithm}

The Incremental Conductance (IncCond) algorithm intending to solve the problem of the perturb and observe $(\mathrm{P} \& \mathrm{O})$ algorithm under rapidly changing atmospheric conditions [17]. IncCond can determine whether the MPPT
Table 1. Parameters of BP SX 150S Solar Module $(\mathrm{GO}=1 \mathrm{KW} / \mathrm{M} 2,25 \mathrm{OC})$

\begin{tabular}{lc} 
Electrical Characteristics & BP SX 150S \\
Maximum Power $\left(\mathrm{P}_{\max }\right)$ & $150 \mathrm{~W}$ \\
Voltage at $\mathrm{P}_{\max }\left(\mathrm{V}_{\text {mp }}\right)$ & $34.5 \mathrm{~V}$ \\
Current at $\mathrm{P}_{\max }\left(\mathrm{I}_{\operatorname{mp}}\right)$ & $4.35 \mathrm{~A}$ \\
Warrented minimum $\mathrm{P}_{\max }$ & $140 \mathrm{~W}$ \\
Short-circuit Current $\left(\mathrm{I}_{\mathrm{sc}}\right)$ & $4.75 \mathrm{~A}$ \\
Open- Circuit Voltage $\left(\mathrm{V}_{\mathrm{oc}}\right)$ & $43.5 \mathrm{~V}$ \\
Temperature coefficient of $\mathrm{I}_{\mathrm{sc}}$ & $0.065 \pm 0.015 \% /{ }^{\circ} \mathrm{C}$ \\
Temperature coefficient of $\mathrm{V}_{\mathrm{oc}}$ & $-160+20 \mathrm{mV} /{ }^{\circ} \mathrm{C}$ \\
Temperature coefficient of Power & $-0.5 \pm 0.05 \% /{ }^{\circ} \mathrm{C}$ \\
NOCT & $47 \pm 2{ }^{\circ} \mathrm{C}$ \\
Max. System Voltage & $600 \mathrm{~V}$ \\
\hline
\end{tabular}

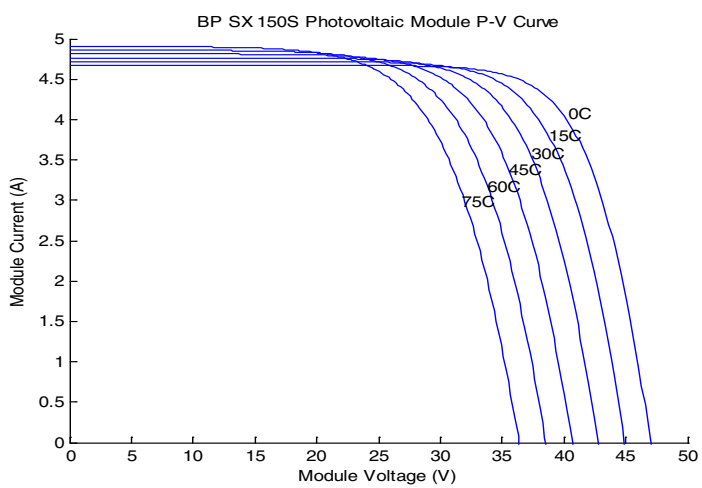

Figure 4. I-V curves of BP SX 150s PV module at various temperatures simulated with the MATLAB $\left(1 \mathrm{KW} / \mathrm{m}^{2}, 25^{\circ} \mathrm{C}\right)$.

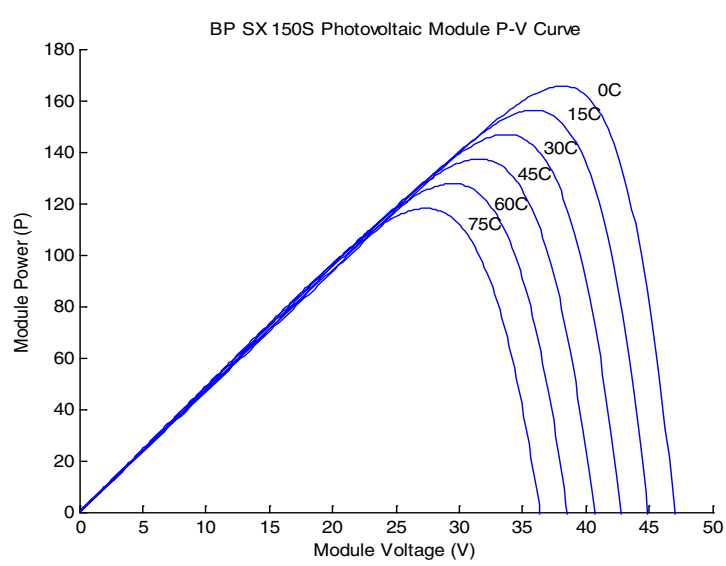

Figure 5. P-V curves of BP SX 150s PV module at various Temperatures simulated with the MATLAB $\left(1 \mathrm{KW} / \mathrm{m}^{2}, 25^{\circ} \mathrm{C}\right)$.

has reached the MPP and stop perturbing the operating point. If the condition is not met, the direction in which the MPPT operating point must be perturbed can be calculated 


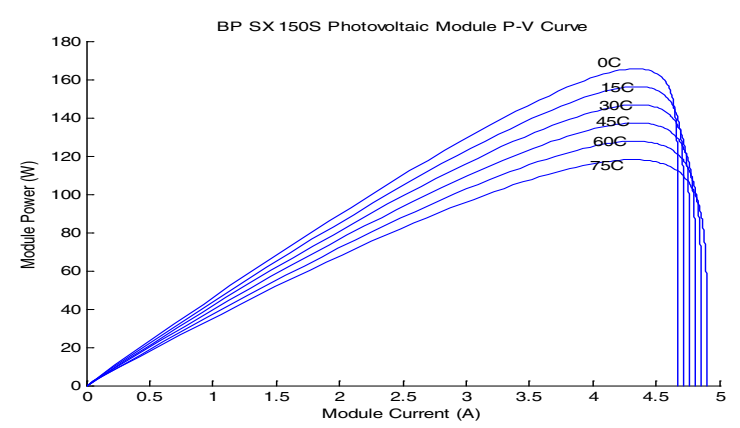

Figure 6. P-I curves of BP SX 150s PV module at various Temperatures simulated with the MATLAB $\left(1 \mathrm{KW} / \mathrm{m}^{2}, 25^{\circ} \mathrm{C}\right)$.

using the relationship between $\mathrm{dI} / \mathrm{dV}$ and $-\mathrm{I} / \mathrm{V}[1,17]$. This algorithm has an advantage over $\mathrm{P} \& \mathrm{O}$ in that it can determine when the MPPT has reached the MPP, where $\mathrm{P} \& \mathrm{O}$ oscillates around the MPP. Also, incremental conductance can track rapidly increasing and decreasing irradiance condition with higher accuracy than $\mathrm{P} \& \mathrm{O}[19,20]$

In this paper, a new approach using decrement resistance algorithm is proposed in place of IncCond algorithm. The basic idea is that the slope of P-I curve becomes zero at the MPP, as shown in Figure 7. It is also possible to find a relative location of the operating point to the MPP by looking at the slopes. The slope is the derivative of the PV module's power with respect to its current and has the following relationships with the MPP.

$\frac{d P}{d I}=0 \quad$ at MPP,

$\frac{d P}{d I}>0 \quad$ at the left of MPP,

$\frac{d P}{d I}<0 \quad$ at the Right of MPP.

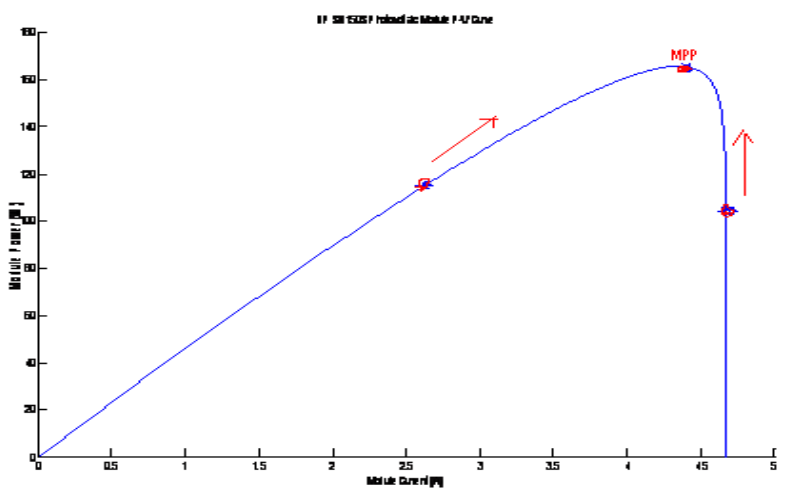

Figure 7. Plot of power vs. current for BP SX150s PV module $\left(1 \mathrm{KW} / \mathrm{m}^{2}, 25^{\circ} \mathrm{C}\right)$.
The above equations are written in terms of voltage and current as follows

$$
\frac{d P}{d I}=\frac{d(V . I)}{d I}=I \frac{d V}{d I}+\frac{V d I}{d I}=\frac{I d V}{d I}+V .
$$

If the operating point is at the MPP, the equation (9) becomes:

$$
\frac{I d V}{d I}+V=0
$$

or

$$
\frac{d V}{d I}=-\frac{V}{I}
$$

If the operating point is at the left side of the MPP, the equation (9) becomes

$$
V+\frac{I d V}{d I}>0
$$

or

$$
\frac{d V}{d I}>-\frac{V}{I}
$$

If the operating point is at the right side of the MPP, the equation (9) becomes:

$$
V+\frac{I d V}{d I}<0
$$

or

$$
\frac{d V}{d I}<-\frac{V}{I} .
$$

The decrement resistance algorithm is depicted in Figure 8. This algorithm is easy to determine and implement than IncCond algorithm.

The output power of the solar PV module changes with change in direction of the sun, change in solar irradiance level, and change in temperature. Also there is a single maximum power point in the PV characteristics of the PV module for a particular operating condition. It is desired that the PV module operates close to this point, i.e., output of the PV module approaches near to MPP. The process of operating PV module at this condition is called as maximum power point tracking (MPPT). Maximization of PV power improves the utilization of the solar PV module [18]. Many MPPT algorithms had been proposed in the past. This method offers the main advantage of providing high efficiency under rapidly changing atmospheric conditions, so it has been employed in the proposed model. 


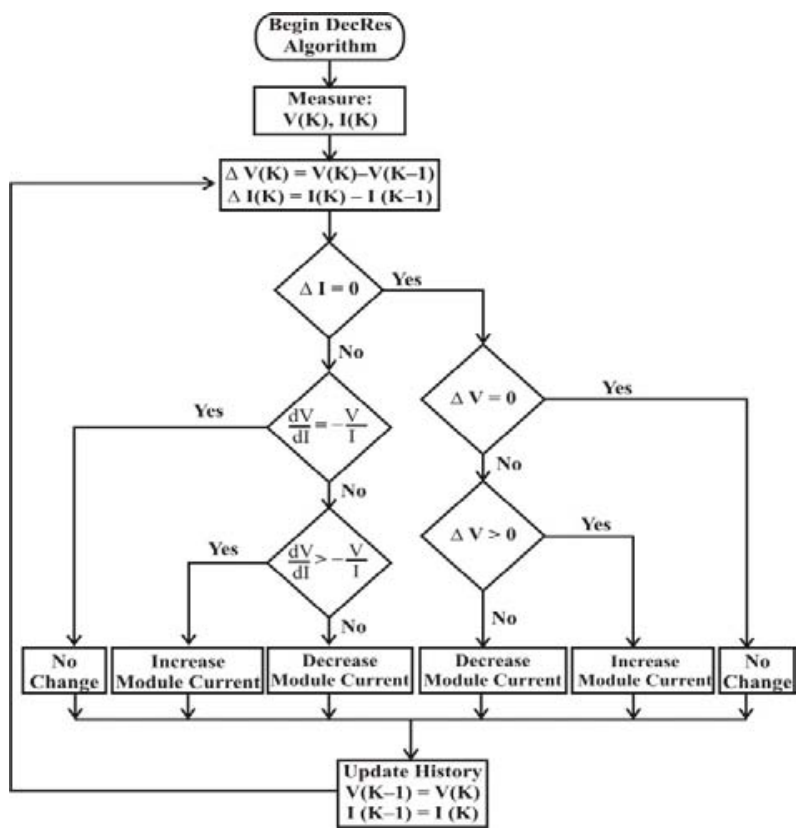

Figure 8. MPPT algorithm.

\section{Simulation Result}

Simulation of PV module using decrement resistance algorithm was done in MATLAb, the simulation results are shown in Figure 9-11. The P-V characteristic for the BP SX150s module using decrement resistance algorithm with maximum power tracking at different irradiance is shown in Figure 9. Figure 10 shows the I-V characteristics for the BP SX150s module using decrement resistance algorithm with maximum current and voltage tracking at different irradiance. Figure 11 shows the P-I characteristics for the BP SX150S module using decrement resistance algorithm with maximum power and current tracking at different irradiance. Figure 12, \& 13 show the module voltage $V_{\text {mp }}$ and Current $\mathrm{I}_{\mathrm{mp}}$ at the maximum power $\mathrm{P}_{\max }$.

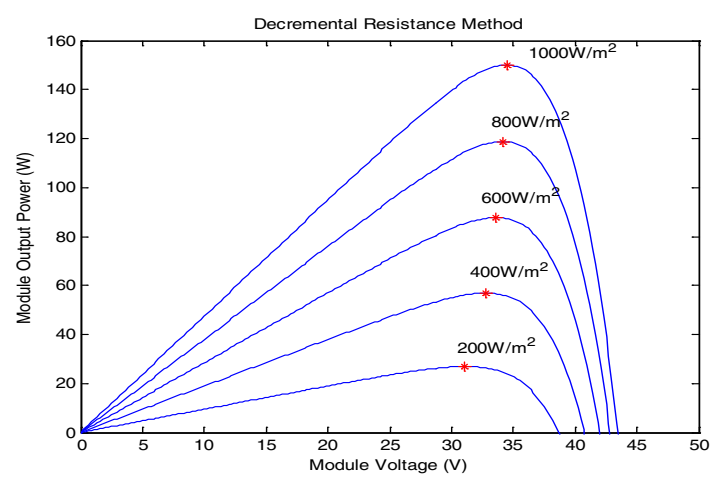

Figure 9. P-V curves for decrement resistance algorithm at various irradiance.

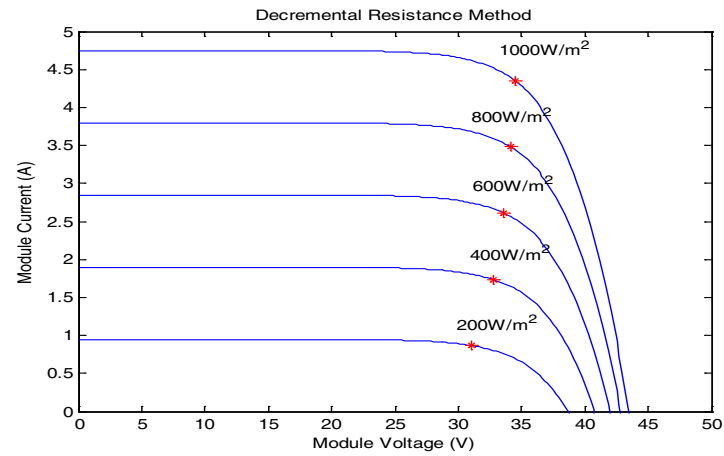

Figure 10. I-V curves for decrement resistance algorithm at various irradiance.

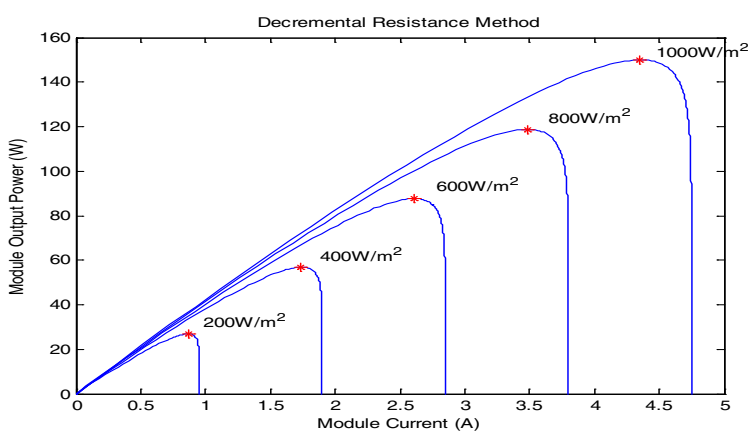

Figure 11. P-I curves decrement resistance algorithm at various irradiance.

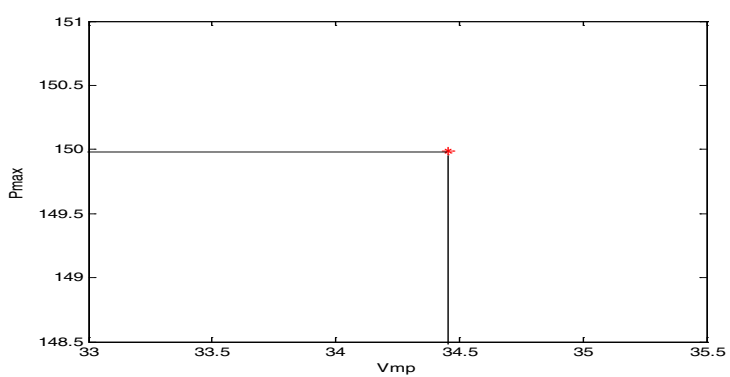

Figure 12. Module voltage at maximum power, $\mathrm{V}_{\mathrm{mp}}$.

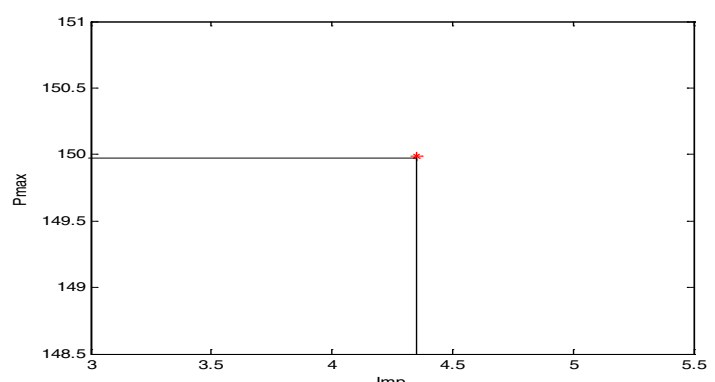

Figure 13. Module current at maximum power, $\mathrm{I}_{\mathrm{mp}}$. 


\section{Conclusion}

The V-I and P-V characteristics of BP SX 150s module are obtained using the MATLAB/Simulation for different values of irradiance. It is observed that the characteristics obtained by decrement resistance algorithm are better then simple PV characteristics of module \& theoretical Characteristics. Also the module voltage $\mathrm{V}_{\mathrm{mp}}$ and Current $\mathrm{I}_{\mathrm{mp}}$ at the maximum power $\mathrm{P}_{\max }$ are obtained which are fairly same as indicated by the manufacturer of $\mathrm{BP}$ SX150S solar panel. The proposed algorithm is better than IncCond algorithm due to easy determination and implementation. Thus the proposed simulation model in conjunction with MPPT algorithm can be used with DC-DC Boost converter to obtain the required dc voltage to supply the dc load.

\section{References}

1. Zainudin H N, and Mekhilef S (2010). Comparison study of maximum power point tracker techniques for PV system, Proceedings of the 14th International Middle East Power Systems Conference (MEPCON'10), Cairo University, 750-755.

2. Chang $\mathrm{Y}-\mathrm{H}$, and Chang $\mathrm{C}-\mathrm{Y}$ (2010). A maximum power point tracking of PV system by scalling fuzzy control, International MultiConference of Engineering and Computer Scientists, Hong Kong.

3. Mekhilef S(2008). Performance of grid connected inverter with maximum power point tracker and power factor control, International Journal of Power Electronics, vol 1, No. 1, 49-62.

4. Vaigundamoorthi M, and Ramesh R (2011). ZVS-PWM active-clamping modified Cuk converter based MPPT for solar PV modules, European Journal of Scientific Research, vol 58, No. 3, 305-315.

5. Walker G (2001). Evaluating MPPT converter topologies using a MATLAB PV module, Journal of Electrical and Electronics Engineering, Australia, vol 21(1), 49-56.

6. Patel H, and Agarwal V (2008). MATLAB basd modeling to study the effects of partial shading on PV array characteristic, IEEE Transactions on Energy Conversion, vol. 23(1), 302-310.

7. Safari A, and Mekhilef S (2011). Simulation and hardware implementation of incremental conductance MPPT with direct control method using Cuk converter, IEEE Transactions on Industrial Electronics, vol 58(4), 1154-1161.
8. Mutoh N, and Inoue T (2007). A control method to charge series-connected ultra electric double-layer capacitors suitable for photovoltaic generation systems combining MPPT control method, IEEE Transactions on Industrial Electronics, vol 54(1), 374-383.

9. Soon J J, and Low K (2012). Photovoltaic model identification using particle swarn optimization with inverse barrier constraint, IEEE Transactions on Power Electronics, vol 27(9), 3975-3983.

10. Hua C, and Lin J et al. (1998). Implementation of a DSP controlled photovoltaic system with peak power tracking, IEEE Transactions on Industrial Electronics, vol 45(1) 99-107.

11. Kim I-S, Kim M-B et al. (2006). New maximum power point tracker using sliding-mode observer for estimation of solar array current in the grid-connected photovoltaic system, IEEE Transactions on Industrial Electronics, vol 53(4), 1027-1035.

12. Xiao W, Lind M G J et al. (2006). Real-time identification of optimal operating points in photovoltaic power systems, IEEE Transactions on Industrial Electronics, vol 53(4), 1017-1026.

13. Villalva M G, Gazoli J R et al. (2009). Comprehensive approach to modeling and simulation of photovoltaic array, IEEE Transactions on Power Electronics, vol 24(5), 11981208.

14. Oi A (2005). Design and simulation of photovoltaic water pumping System, Master's Thesis, California Polytechnic State University, San Luis Obispo.

15. Tsai H, Tu C et al. (2008). Development of generalized photovoltaic model using MATLAB/SIMULINK, Proceedings of the World Congress on Engineering and Computer Science, San Francisco, USA.

16. Solar B P (2001). SX 150-150Watt multicrystalline photovoltaic module datasheet.

17. Hussein K H, Muta I et al. (2005). Maximum photovoltaic power tracking: an algorithm for rapidly changing atmospheric conditions, IEE Proceedings- Generation, Transmission and Distribution, vol 142(1), 953-959.

18. Gupta R, Gupta G et al. (2010), Modelling and Design of MPPT controller for a PV module using PSCAD/EMTDC, Innovative Smart Grid Technologies Conference Europe (ISGT Europe), 2010 IEEE PES.

19. Liu F, Duan S et al. (2008). A variable step size INC MPTT method for PV system, IEEE Transactions on Industrial Electronics, vol 55(7), 2622-2628.

20. Esram T, and Chapman P L (2007). Comparison of Photovoltaic Array Maximum Power Point Tracking Techniques, IEEE Transactions on Energy Conversion, vol 22(2), 439-449. 